\title{
APLIKASI MIKROKONTROLER AT89S51 PADA PENGATURAN SUHU BAK PENAMPUNGAN AIR KAMAR MANDI DIDUKUNG BAHAS PEMROGRAMAN ASSEMBLER
}

\author{
Feri Oktavianus ${ }^{1}$, Eka Sabna ${ }^{2}$ \\ ${ }^{1}$ Sistem Komputer Universitas Putra Indonesia YPTK Padang \\ Jl.Raya Lubug Begalung Padang SUMBAR \\ 2 Teknik Informatika STMIK Hang Tuah Pekanbaru \\ J1. Mustafa Sari No.5 Pekanbaru Riau \\ Email : es3jelita@yahoo.com
}

\begin{abstract}
ABSTRAK
Penelitian ini bertujuan untuk mengembangkan sistem pengontrol shower serta pengisian bak penampungan menggunakan sensor suhu sebagai sensor dan mikrokontroler sebagai pengendali proses. Manfa'at yang didapat dari sistem pengontrolan shower ini adalah mengefektifkan penggunaan air untuk mandi, efisiensi waktu dalam kegiatan mandi dan pengurangan tenaga manusia dalam proses mandi.

Penelitian ini dilakukan dengan merancang, membuat dan mengimplementasikan komponen - komponen sistem yang meliputi mikorokontroler sebagai pengendali proses, sensor suhu sebagai media pendeteksi, element sebagai pemanas dan pompa air untuk memompakan air. Hasil penelitian menunujukkan alat yang dibuat dapat berfungsi dengan baik dan dapat dikembangkan untuk skala yang lebih besar.
\end{abstract}

Kata Kunci : pengontrolan shower serta pengisian bak penampungan, mikrokontroler, sensor suhu, element pemanas, pompa air

\section{ABSTRACT}

This research aim to to develop system shower control and also admission filling of relocation basin use temperature censor as and censor of mikrocontroller as controller of process. benefit which earning. of system control of this shower is to streamline usage of water for the bath of, time efficiency in activity of bath and reduction of manpower in course of bath.

This research is designed, component implementation and making system component covering mikorokontroler as controller of process, temperature censor as media detect, element as water pump and heater for water pump. Result of research of made appliance showing can function better and can be developed for the scale of larger ones

Keywords : Shower control and also admission filling of relocationbasin, microcontroller, temperature censor, heater element, water pump 


\section{PENDAHULUAN}

Alat-alat sejenis pengontrol semakin dibutuhkan untuk membantu pekerjaan manusia. Manusia menginginkan pekerjaan yang dilakukan secara lebih mudah, cepat, tepat dan dengan kelebihan akalnya manusia berfikir untuk mengembangkan alat yang seefisien mungkin. Berbagai alat yang digunakan manusia pada saat sekarang ini diarahkan pada teknologi yang maju dan berkembang, sehingga manusia tidak membuang waktu, biaya dan tenaga yang percuma.

Setiap hari orang selalu membersihkan diri dan hal yang paling penting yaitu mandi. Pada masa sekarang ini peralatan mandi masih menggunakan sistem manual, dimana setelah pengguna menghidupkan shower, air akan terus mengalir sampai pengguna mematikan kembali. Jika pengguna lupa mematikan shower tersebut maka air tersebut akan mengalir terus sampai air di bak penampungan habis. Akibatnya akan terjadi pemborosan karena pada waktu pengguna tidak menggunakan air tersebut shower masih terus terbuka dan air akan terbuang sia-sia.

Salah satu cara untuk mengatasi hal tersebut, yaitu dengan cara menggunakan alat pengontrol shower secara otomatis dimana air tidak akan keluar jika seseorang tidak berdiri tepat dibawah shower, sebaliknya jika seseorang berdiri tepat dibawah shower air akan akan keluar. Ini dilakukan dengan mekanisme pendeteksian tubuh seseorang menggunakan sensor ultrasonik. Sensor ultrasonik akan mengirimkan data ke mikrokontroler sehingga mikrokontroler memberi perintah mesin atau alat untuk bekerja.

\section{DASAR TEORI}

\subsection{Teori Sistem}

Pendekatan dua kelompok didalam mendefenisikan sistem yaitu menekankan pada prosedurnya dan yang menekankan pada komponen atau elemennya. Pendekatan sistem yang lebih menekankan pada prosedur mendefenisikan suatu sistem adalah suatu jaringan kerja dari prosedur-prosedur yang saling berhubungan, berkumpul bersama-sama untuk melakukan suatu kegiatan atau untuk menyelesaikan suatu sasaran yang tertentu.

Pendekatan sistem yang merupakan jaringan kerja dari prosedur lebih menekankan urutan-urutan operasi didalam sistem. Sedangkan pendekatan sistem yang lebih menekankan pada elemen atau komponennya mendefenisikan suatu sistem adalah kumpulan dari elemen-elemen yang berinteraksi untuk mencapai suatu tujuan tertentu.

\subsection{Siklus Hidup Pengembangan Sistem}

Pengembangan sistem informasi yang berbasis komputer dapat merupakan tugas kompleks yang membutuhkan banyak sumber daya dan dapat memakan waktu berbulanbulan untuk menyelesaikannya. Proses pengembangan sistem melewati beberapa tahapan dari mulai sistem itu direncanakan sampai dengan sistem tersebut diterapkan, dioperasikan dan dipelihara. Bila operasi sudah dikembangkan masih timbul kembali permasalahan-permasalahan yang kritis serta tidak dapat diatasi dalam tahap pemiliharaan sistem, maka perlu dikembangkan lagi suatu sistem untuk mengatasinya dan proses ini kembali ke tahap pertama, yaitu tahap perencanaan sistem siklus ini disebut dengan siklus hidup suatu sistem (system life cycle). Daur atau siklus dari pengembangan sistem merupakan suatu bentuk yang digunakan untuk menggambarkan tahapan utama dan langkah-langkah dalam tahapan tersebut dalam pengembangannya. 
Pada system life cycle, tiap-tiap dari pengembangan sistem dibagi menjadi tahapan kerja. Tiap-tiap tahapan ini mempunyai karakteristik tersendiri. Tahapan utama siklus hidup pengembangan sistem dapat terdiri dari tahapan perencanaan sistem (system planning), analisa sistem (system analysis), desain sistem (system design), seleksi sistem (system selection), implementasi sistem (system implementation) dan perawatan sistem (system maintenance). Tahapan-tahapan seperti ini sebenarnya merupakan tahapan dalam pengembangan sistem teknik (engineering system). Tampak bahwa daur hidup dari sistem teknik dan sistem informasi dapat sama atau mirip. Hal ini tidaklah kebetulan, pengembangan sistem informasi adalah proses teknik dan proses semacam ini harus mengikuti langkah-langkah yang sama serta prinsip-prinsip umum dari sistem teknik. Istilah software engineering merupakan proses pengembangan perangkat lunak yang merupakan subsistem dari pengembangan sistem informasi. Secara umum siklus hidup pengembangan sistem dapat digambarkan berikut ini:

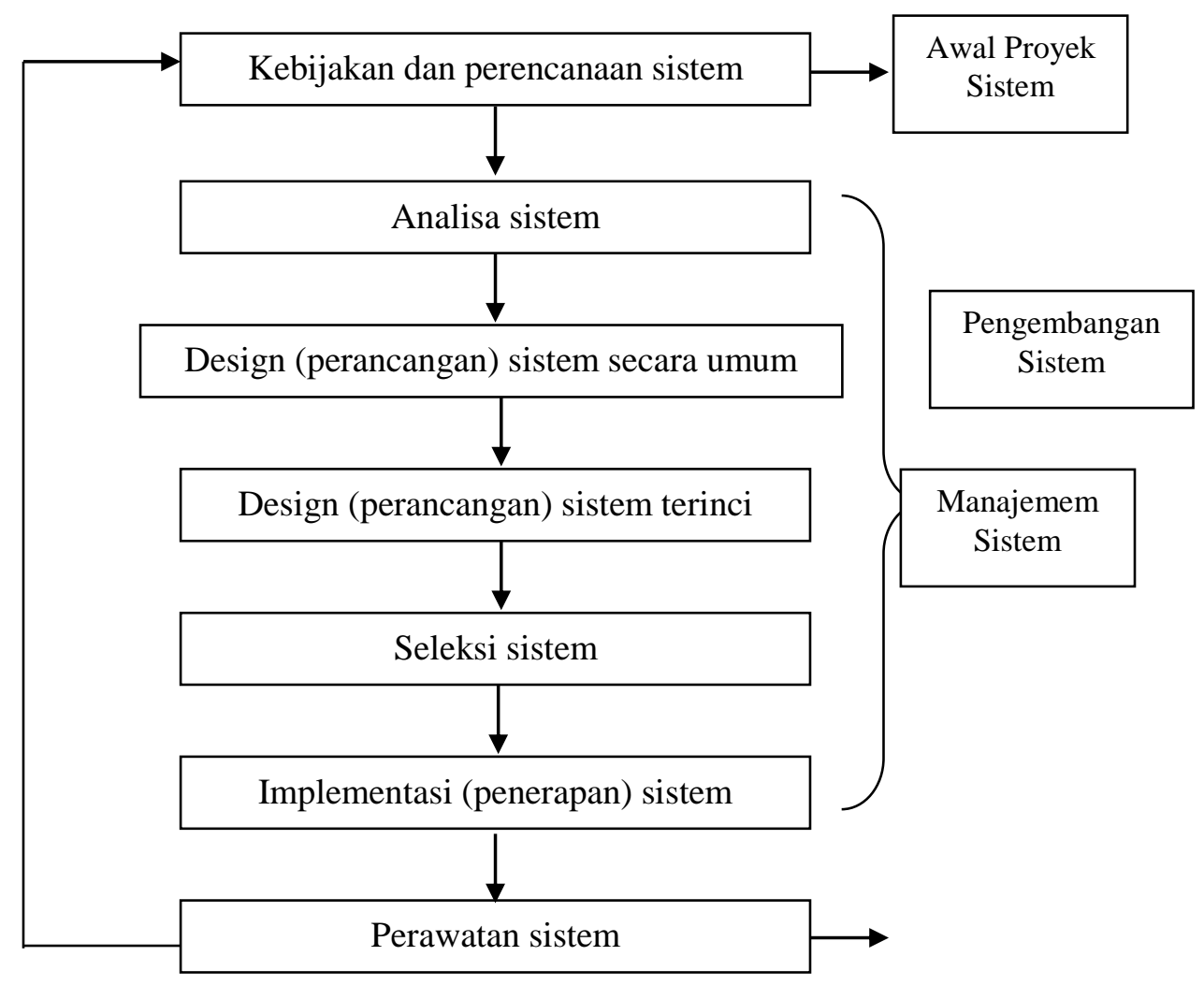

Gambar 2.1 Siklus Hidup Pengembangan Sistem

\subsection{Sistem Kontrol}

Sistem kendali adalah gabungan kerja alat-alat kendali untuk menghasilkan suatu keinginan yang membentuk sistem. Peralatan-peralatan dalam sistem kendali ini disebut dengan instrumentasi pengendali yang terdiri dari :

\section{Sensor}

a. Menyediakan input dan proses dan dari lingkungan eksternal. 
b. Mengubah informasi fisik lainnya seperti suhu, tekanan, laju aliran dan posisi untuk sinyal listrik.

c. Terkait dengan variabel fisik pada cara yang diketahui sehingga sinyal listriknya dapat digunakan untuk memonitoring dan mengontrol proses.

\section{Interface Operator Mesin}

a. Memungkinkan input dan manusia untuk mengadakan kondisi starting atau mengubah kontrol proses.

b. Memungkinkan manusia memberikan input melalui berbagai sejenis saklar pengontrol dan keypad.

c. Mengoperasikan dan menggunakan input yang diberikan. Informasi yang dapat mencakup emergency (keadaan darurat) menutup atau mengubah kecepatan, jenis proses yang digerakkan, jumlah barang yang dibuat, atau reset untuk pencampur tumpukan.

\section{Pengkondisian Sinyal}

a. Melibatkan pengubah sinyal input dan output path bentuk yang dapat digunakan.

b. Mencakup teknik yang mengkondisikan sinyal, misalnya amplifikasi (penguatan), pelemahan, konverter $\mathrm{A} / \mathrm{D}$ dan konverter $\mathrm{D} / \mathrm{A}$.

\section{Aktuator (Penggerak)}

a. Mengubah sistem sinyal output listrik menjadi aksi fisik.

b. Mempunyai penggerak proses yang melibatkan keran kontrol aliran, pompa, motor stepping dan relai daya.

c. Melalui penggerak eksternal, misalnya meter, monitor tabung sinar katoda (chatode ray tube/CRT), printer tanda bahaya, dan lampu petunjuk, menunjukkan status proses atau mulai dan variabel proses tertentu (interface mesin operator).

d. Mengirimkan output secara langsung dan pengontrolan ke komputer untuk menyimpan data dan menganalisis hasil (interface mesin-mesin).

\section{Pengontrol}

a. Membuat keputusan sistem didasarkan pada sinyal input.

b. Membangkitkan sinyal output yang mengoperasikan penggerak untuk melakukan keputusan.

Sistem kontrol dapat diklasifikasikan sebagai loop terbuka dan loop tertutup. Sistem kontrol loop tertutup (Closed-Loop Control System) merupakan sistem kontrol yang sinyal keluarannya mempunyai pengaruh langsung pada aksi pengontrolan http://ariefwahyupurwito. Sistem tersebut mengukur output yang sesungguhnya dari proses dan membandingkan dengan output yang dikehendaki. Pengaturan dibuat secara terus menerus oleh sistem kontrol sampai perbedaan antara output yang dikehendaki dan sesungguhnya sekecil dan sepraktis mungkin. Sistem kontrol loop tertutup dapat disebut dengan sistem kontrol umpan balik.

\subsection{Mikrokontroler AT89S51}

Mikrokontroler AT89S51 adalah sebuah IC mikrokontroler yang membutuhkan daya rendah dan merupakan IC tipe CMOS 8 bit mikrokomputer dengaa $4 \mathrm{~K}$ bytes ROM yang bisa diprogram dan dihapus (PEROM). MC AT89S51 dirancang oleh ATMEL's dengan kemampuan teknologi memori nonvolatile dan kompatibel dengan instruction set dan pinout industri standar MCS-51 ${ }^{\mathrm{TM}}$. Keistimewaan dari AT89S51 adalah [(www.atmel.com)]:

1. Kompatibel dengan produk MCS-51

2. $4 \mathrm{~K}$ bytes memori yang bisa diprogram dan dihapus sebanyak 1000 kali. 
3. Dapat beroperasi dengan clock dari $3 \mathrm{MHz}-24 \mathrm{Mhz}$

4. 128 X 8-bit internal RAM

5. 32 jalur port $\mathrm{I} / \mathrm{O}$ bidirectional

6. Dua buah timer/counter 16-bit.

7. Programmable serial channel.

8. Six Interrupt Sources

\subsection{Konfigurasi Pin Mikrokontroler AT89S51}

Berikut ini adalah gambar dari pin-pin mikrokontroler AT89S51 dan keterangan dari pin-pin mikrokontroler AT89S51 [(www.atmel.com)].

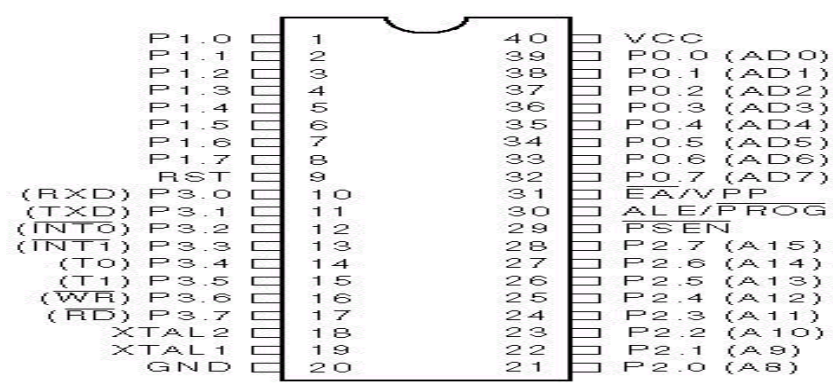

\section{Gambar 2.2. Pin-pin Mikrokontroler AT89S51}

Keterangan Pin :

1. Pin 1 sampai 8 : Port 1

Port 1 ini merupakan 8-bit bidirectional I/O port yang dapat digunakan sebagai input maupun output.

2. Pin $9:$ Reset

Digunakan untuk mereset sistem.

3. Pin 10 sampai $17:$ Port 3

8 bit bidirectional I/O Port. Disamping itu bisa juga berfungsi sebagai :
a. Port 3.0
: Berfungsi sebagai RXD (Serial Input Port)
b. Port 3.1
:Berfungsi sebagaiTXD (Serial Output Port)
c. Port 3.2
: Berfungsi sebagai INT 0 (external interrupt 0$)$
d. Port 3.3
: Berfugsi sebagi INT 1 (external interrupt 1 )
e. Port 3.4
: Berfungsi sebagai WR (Aktiflow)
f. Port 3.5
: Berfungsi sebagai RD (Aktif Low)

4. Pin $18: \mathrm{XTAL}-2$

Output dari Penguat Osilator.

5. Pin $19:$ XTAL - 1

Input dari penguat osilator yang ada dalam mikrokontroler AT89S51.

6. Pin 20 : Gnd

Dihubungkan ke ground.

7. Pin 21 sampai $28:$ Port 2

Port 2 ini merupakan 8-bit bidirectional I/O port. Pada port ini, disediakan alamat untuk mengakses ekternal memori.

8. Pin 29 : PSEN

Akan diaktifkan apabila kita ingin membaca program ekternal memori.

9. Pin 30 : ALE / PROG

10. Pin $31:$ EA 
External Access Enable (EA ) disambungkan ke ground untuk mengambil kode instruksi dari program memori eksternal dimulai dari lokasi $0000 \mathrm{H}$ sampai FFFFH. Pin EA dihubungkan ke VCC jika melaksanakan program internal.

11. Pin 32 sampai 39 : Port 0

Port paralel 8 bit bidirectional. Bila digunakan untuk mengakses memori luar, port ini akan memultipleks alamat memori dengan data.

12. Pin 40 : VCC

Pin 40 ( Vcc ) dihubungkan ke Vcc ( +5 volt ).

\subsection{Blok Diagram Mikrokontroler AT89S51}

Pada bagian ini digambarkan struktur dasar arsitektur yang terdapat pada piranti mikrokontroler [(http://www.atmel.com)] :

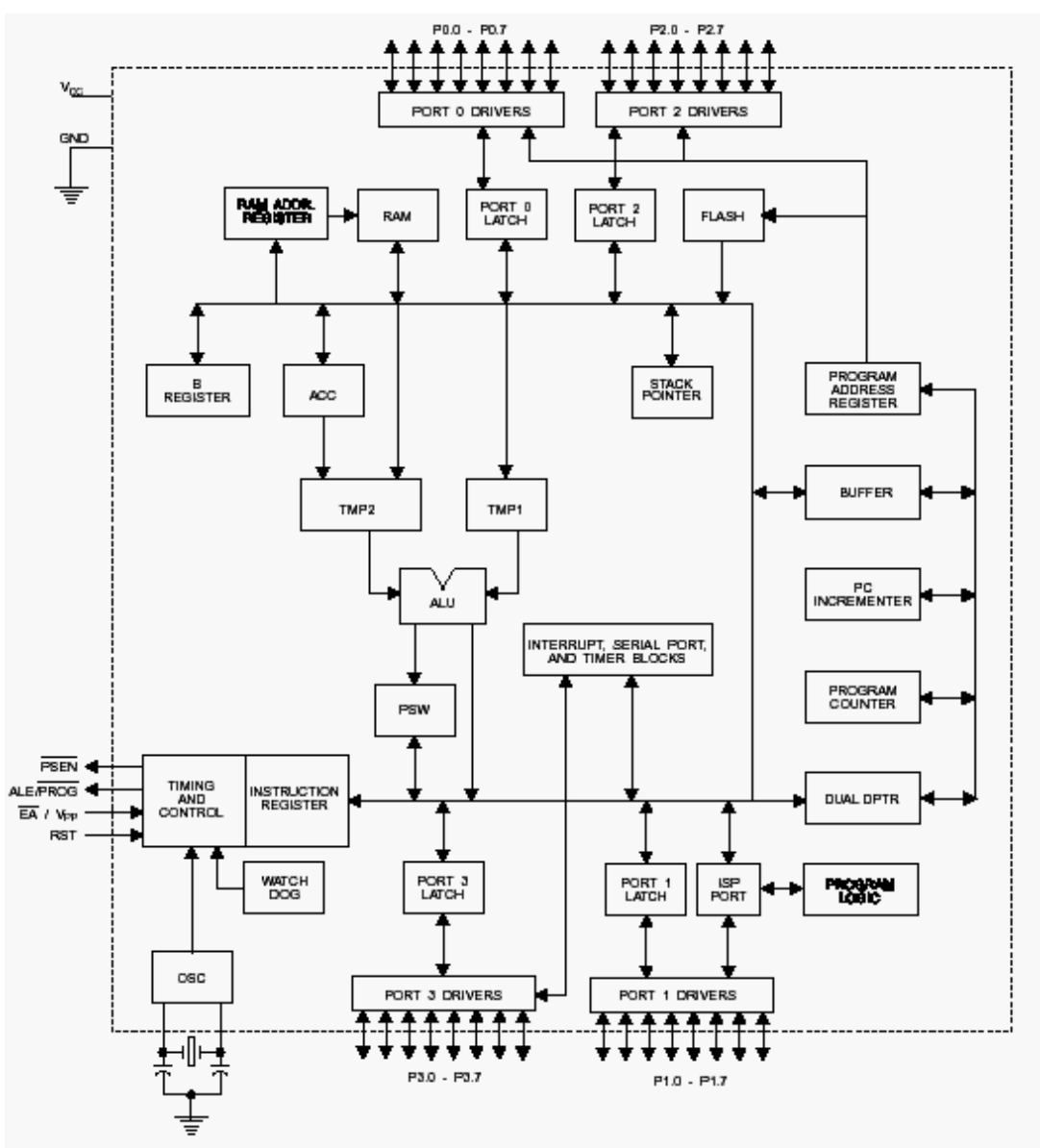

Gambar 2.3 Blok Diagram struktur dasar arsitektur AT89S51 


\section{Timer}

Mikrokontroler AT89S51 hadir dengan 2 timer 16-bit (timer 0 dan timer 1) yang masing-masing terdiri dari dua register 8-bit. Timer 0 dan timer 1 dapat digunakan sebagai timer maupun counter. Timer dapat digunakan untuk membuat time delay sedangkan counter dapat digunakan sebagai penghitung suatu ekternal event yang terjadi dalam interval waktu tertentu. Event dapat dipresentasikan sebagai sinyal edge (falling atau rissing). Kedua timer tersebut dapat membangkitkan interrupt ke CPU. Sebuah timer bekerja dengan cara mencacah. Berikut adalah sinyal pin MC AT89S51 yang berhubungan dengan fungsi timer [( $\underline{w w w . a t m e l . c o m})]$ :

\section{Register}
a. T0 (Pin P3.4) input eksternal timer 0.
b. T1 (Pin P3.5) input eksternal timer 1.

Register-register yang digunakan pada mikrokontroler AT89S51 meliputi Accumulator, Register R, Register B, DPTR (Data Pointer), PC (Program Counter ) dan SP (Stack Pointer) [(www.atmel.com)].

a. Accumulator

Register ini berfungsi untuk mengakumulasi hasil dari instruksi-instruksi. Accumulator dapat menampung 8 bit (1 byte) data dan merupakan register yang paling sering digunakan.

b. Register $\mathrm{R}$

Register $\mathrm{R}$ yang digunakan sering dinamakan dengan R0, R1,R2, R3, R4, R5, R6 dan R7. Register-register ini digunakan sebagai register pembantu dalam penyimpanan data pada banyak operasi. Tanpa register-register ini Accumulator tidak dapat melakukan operasi dua operand.

c. Register $\mathrm{B}$

Register ini hanya digunakan dalam dua instruksi keluarga MCS 51 yaitu instruksi MUL AB dan DIV AB. Jika diinginkan untuk mengalikan atau membagi accumulator A dengan suatu harga, maka simpanlah harga tersebut kedalam Register B dan kemudian jalankan instruksinya.

d. DPTR (Data Pointer)

DPTR adalah satu-satunya register yang dapat diakses 16 bit dalam keluarga MCS 51. DPTR ini digunakan untuk menunjuk pada lokasi suatu data. Jika AT89S51 mengakses memori eksternal, komponen ini akan mengakses memori eksternal dengan alamat yang ditunjukan oleh DPTR.

e. PC (Program Counter)

PC adalah alamat 2 byte yang memberi tahu AT89S51 di mana instruksi selanjutnya akan dilaksanakan. Saat AT89S51 inisialisasi, PC selalu berisi data 0000h dan bertambah satu setiap satu instruksi terkerjakan.

f. SP (Stack Pointer)

SP ini digunakan untuk menunjukan dimana harga berikutnya yang akan diambil dari stack. Jika suatu harga dimasukan kedalam stack, AT89S51 pertama-tama akan menambah harga SP dan kemudian menyimpan harga tersebut pada alamat memori yang bersesuaian. Demikian juga jika suatu harga diambil dari stack, maka AT89S51 akan mengambil harga dari stack dan kemudian mengurangi harga SP (Stack Pointer).

\section{Memori}

Mikrokontroler AT89S51 memiliki tiga tipe utama dari memori yaitu Program Memori, RAM Internal dan RAM eksternal [(www.atmel.com $)$ ].

a. Program Memori 
Program Memori adalah memori yang menyimpan program yang terbaru (aktual) dari AT89S51 yang akan dijalankan. Didalam AT89S51 ini sudah terdapat program memori internal sebesar $4 \mathrm{~K}$, namun dapat diekspansikan dengan menggunakan EPROM (Ereasable Programmable Read Only Memory) hingga $64 \mathrm{~K}$.

b. RAM Internal

Mikrokontroler AT89S51 memiliki 128 byte RAM internal. RAM internal ini terdapat dalam keping AT89S51, karenanya memori ini adalah memori tercepat yang ada dalam sistem, dan juga tempat yang paling fleksibel untuk membaca, menulis dan memodifikasi isi datanya. RAM internal ini bersifat volatile yang berarti jika AT89S51 mengalami reset, maka isi memori akan hilang.

c. RAM eksternal

RAM eksternal adalah merupakan kebalikan dari RAM internal, dimana memorinya tidak terdapat didalam keping AT89S51 tetapi terletak diluarnya. Karena memorinya terletak diluar maka tidak fleksibel untuk mengaksesnya sehingga memakan waktu dan instruksi yang lebih banyak. Namun jika RAM internal terbatas 128 byte, maka RAM eksternal mampu mengalamati spasi hingga $64 \mathrm{~K}$.

\section{SBC (Single Board Controller) AT89S51}

SBC adalah merupakan sebuah board yang memiliki internal reprogrammable flash memori. Hanya dengan menambahkan sedikit rangkaian/komponen eksternal (Interface dan Rangkaian Driver), berbagai aplikasi yang sangat berguna dapat dibangun dengan cepat. Selain itu SBC ini telah menyediakan perangkat komunikasi serial RS-232 (serial port) sehingga dapat berkomunikasi dengan peralatan luar yang mempunyai serial port. Bila dibutuhkan RAM, ROM dengan kapasitas lebih besar (hingga 64 Kbyte) dapat digunakan eksternal memori [(www.avrfreaks.com)].

\subsection{Sensor Suhu LM 35 DZ}

Temperatur adalah besaran lingkungan yang sering diukur, karena memiliki pengaruh besar pada besaran fisik, listrik, kimia, mekanik maupun biologi. Sensor suhu akan memberikan input ke system kontrol sehingga suhu pada sistem dapat terkontrol pada suatu batas temperatur tertentu. Mendeteksi suhu digunakan sebuah sensor suhu LM 35 DZ yang dapat dikalibrasikan langsung dalam C, LM 35 DZ, ini difungsikan sebagai basic temperature sensor seperti pada gambar 2.4.

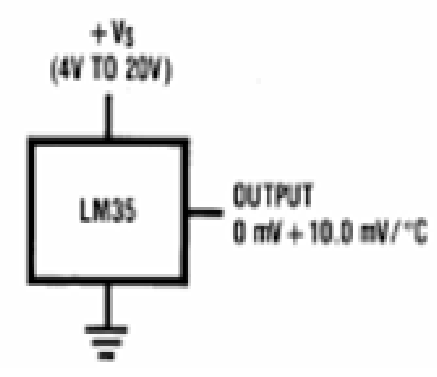

\section{Gambar 2.4 LM 35 DZ basic temperature sensor}

Vout dari LM $35 \mathrm{DZ}$ ini dihubungkan dengan ADC (Analog To Digital Converter). Dalam suhu kamar $\left(25^{\circ} \mathrm{C}\right)$ tranduser ini mampu mengeluarkan tegangan $250 \mathrm{mV}$ dan $1,5 \mathrm{~V}$ pada suhu $150^{\circ} \mathrm{C}$ dengan kenaikan sebesar $10 \mathrm{mV} /{ }^{\circ} \mathrm{C}$. 


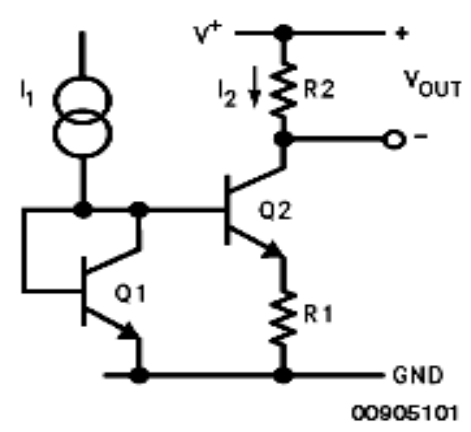

Gambar 2.5 Rangkaian internal sensor suhu LM35DZ

\subsection{ADC 0804}

Rangkaian ADC 0804 berfungsi sebagai pengubah tegangan analog yang berasal dari input analog menjadi bentuk digital 8 bit. ADC ini memiliki 20 kaki. ADC 0804 ini mempunyai range tegangan 0 Volt sampai dengan 5 Volt dan mempunyai dua masukan yaitu Vin $=\operatorname{Vin}(+)-\operatorname{Vin}(-)$, sehingga untuk keperluan ini maka Vin(-) harus diground kan.

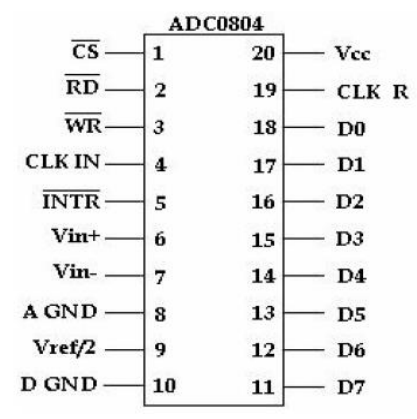

\section{Gambar 2.6. Konfigurasi Pin ADC 0804}

\subsection{Tombol/switch}

Tombol/switch adalah sebuah perangkat yang digunakan untuk memutuskan jaringan listrik, atau untuk menghubungkannya. Jadi switch pada dasarnya adalah alat penyambung atau pemutus aliran listrik. Selain untuk jaringan listrik arus kuat, saklar berbentuk kecil juga dipakai untuk alat komponen elektronika arus lemah.

Secara sederhana, switch terdiri dari dua bilah logam yang menempel pada suatu rangkaian, dan bisa terhubung atau terpisah sesuai dengan keadaan sambung (on) atau putus (off) dalam rangkaian itu. Material kontak sambungan umumnya dipilih agar supaya tahan terhadap korosi. Kalau logam yang dipakai terbuat dari bahan oksida biasa, maka switch akan sering tidak bekerja. Mengurangi efek korosi ini, paling tidak logam kontaknya harus disepuh dengan logam anti korosi dan anti karat. Tombol mempunyai bentuk dua kondisi diantaranya kondisi ON dan OFF. Tombol pada kondisi ON 
mempunyai resistansi sangat besar sekali, sedangkan pada kondisi OFF resistansinya sangatlah kecil. Adapun karateristik dari tombol / switch ini adalah :

1. Tegangan maximum (Off)

2. Arus maximum $(\mathrm{On})$

3. Resistansi terbuka (Off)

4. Resistansi menutup (On)

Dimana dalam alat yang akan dibuat ini lebih cenderung menggunnakan Push Button Switch. Rangkaian tombol terdiri dari sebuah Push Button Switch (Saklar Kontak Tukar) yang terhubung langsung ke mikrokontroler AT89S52. Adapun gambar rangkaiannya dapat dilihat pada gambar 2.7.

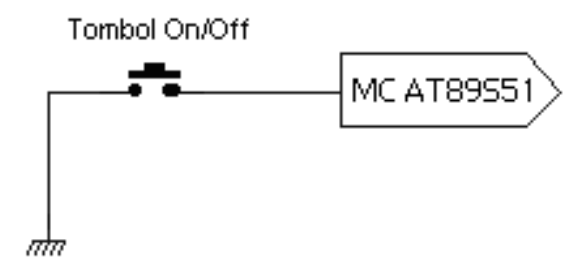

\section{Gambar 2.7 Rangkaian Tombol / switch}

Kerja rangkaian switch ini adalah jika ground diarahkan ke mikrokontroler melalui rangkaian tombol. Jika tombol ditekan, arus akan mengalir dari mikrokontroler ke ground. Ini memberikan logika 0 pada pin mikrokontroler.

\subsection{Motor DC}

Motor arus searah (DC) adalah suatu mesin yang berfungsi mengubah tegangan listrik DC menjadi tenaga mekanis dimana tenaga gerak merupakan putaran dari pada rotor. Dalam kehidupan sehari-hari, motor DC terdapat pada motor starter mobil, tape recorder, mainan anak-anak dan sebagainya. Pada prinsipnya motor arus searah dapat dipakai sebagai generator arus searah, sebaliknya generator arus searah dapat dipakai sebagai motor arus searah.

Pada prinsipnya, setiap jenis motor listrik dapat digunakan dalam perancangan pengontrolan secara elektronik terhadap kecepatan dan daya yang disesuaikan dengan beban yang akan digerakkan oleh motor tersebut. Pada perancangan dan pembuatan alat ini, digunakan motor DC yang berfungsi untuk menggerakkan belt conveyer. Untuk dapat menggerakkan motor DC ini maka diperlukan suatu rangkaian tambahan berupa rangkaian penguat daya yang disebut dengan rangkaian penggerak (driver circuit).

Kecepatan motor DC dapat dikendalikan dengan mengubah tegangan yang dikenakan pada motor, pada dasarnya motor DC merupakan peralatan listrik yang mengubah energi listrik menjadi energi mekanis.

Motor terdiri dari dua bagian utama yaitu stator dan rotor. Stator atau bagian diam terdiri dari magnet permanen, dan rotor atau bagian yang berputar terdiri dari kumparankumparan tembaga yang ditanam dicelah-celah inti besi rotor.

\section{ANALISA DAN HASIL}

\subsection{Diagram Konteks}


Secara umum bentuk dari simulator sistem pengontrol shower serta pengisian bak penampungan otomatis ini terdiri dari sistem mekanik dan rangkaian elektronika. Gerakan dari sistem mekanik akan ditentukan oleh gerakan simulasi yang digunakan, sedangkan rangkaian elektronika berfungsi untuk memberikan data berupa sinyal yang nantinya data ini akan diolah oleh program yang ada pada mikrokontroler.

Proses perancangan alat ini, diperlukan gambaran yang memperlihatkan hubungan sebuah proses dengan dunia luarnya. Gambaran hubungan tersebut dapat dilihat pada gambar 3.1 dibawah ini :

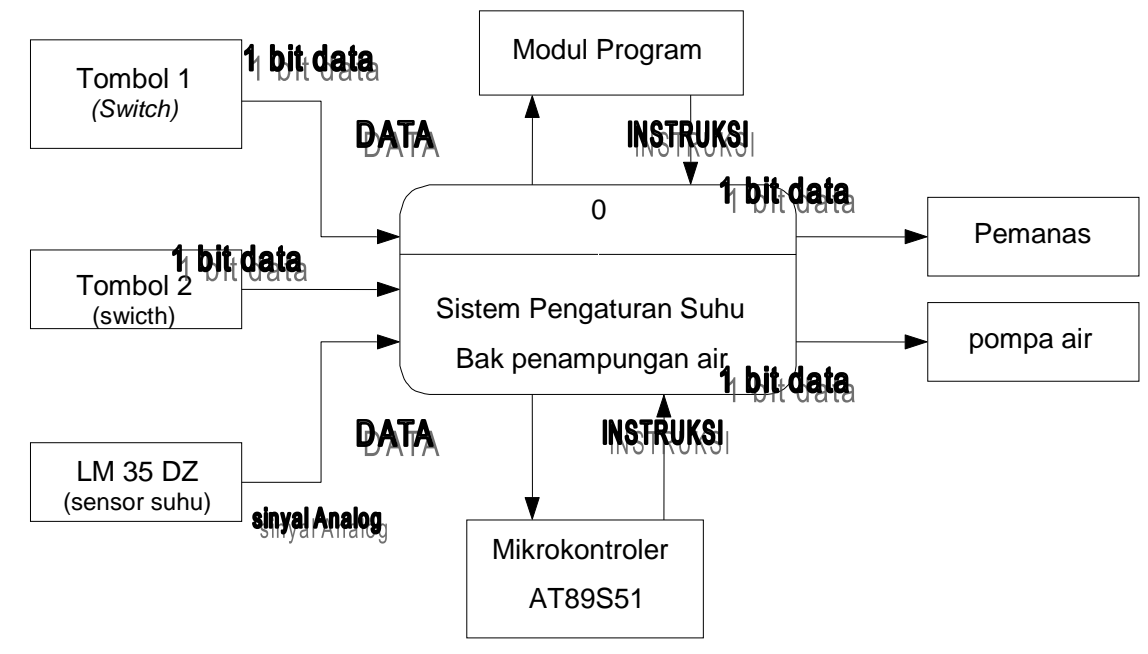

Gambar 3.1 Context Diagram Sistem Kontrol

Tombol digunakan sebagai masukan pada sistem untuk mengaktifkan dan menonaktifkan pemanas air, pada tombol terdiri dari 2 buah kondisi air panas dan dingin. Sensor suhu digunakan untuk mengukur suhu pada bak penampungan agar suhu untuk kondisi air hangat masih dalam batas normal suhu yang dapat diterima oleh tubuh manusia. Mikrokontroler merupakan piranti pemrosesan dari masukan yang diterima dari tombol, sensor suhu, dan ADC untuk menghasilkan keluaran yang mengaktifkan Pompa Air, dan pemanas air. Pompa air berfungsi sebagai media yang akan memompa air dari bak penamapungan air ke shower. Pemanas Air merupakan piranti untuk menghangatkan air dalam bak penampungan untuk mneghasilkan kondisi air hangat.

\subsection{Data Flow Diagram (DFD) Level 0}

Menguraikan lebih terinci dari sistem yang dirancang adalah menggunakan Data Flow Diagram level 0. Data Flow Diagram level 0 ini diuraikan berdasarkan Context Diagram yang telah dijabarkan sebelumnya. 


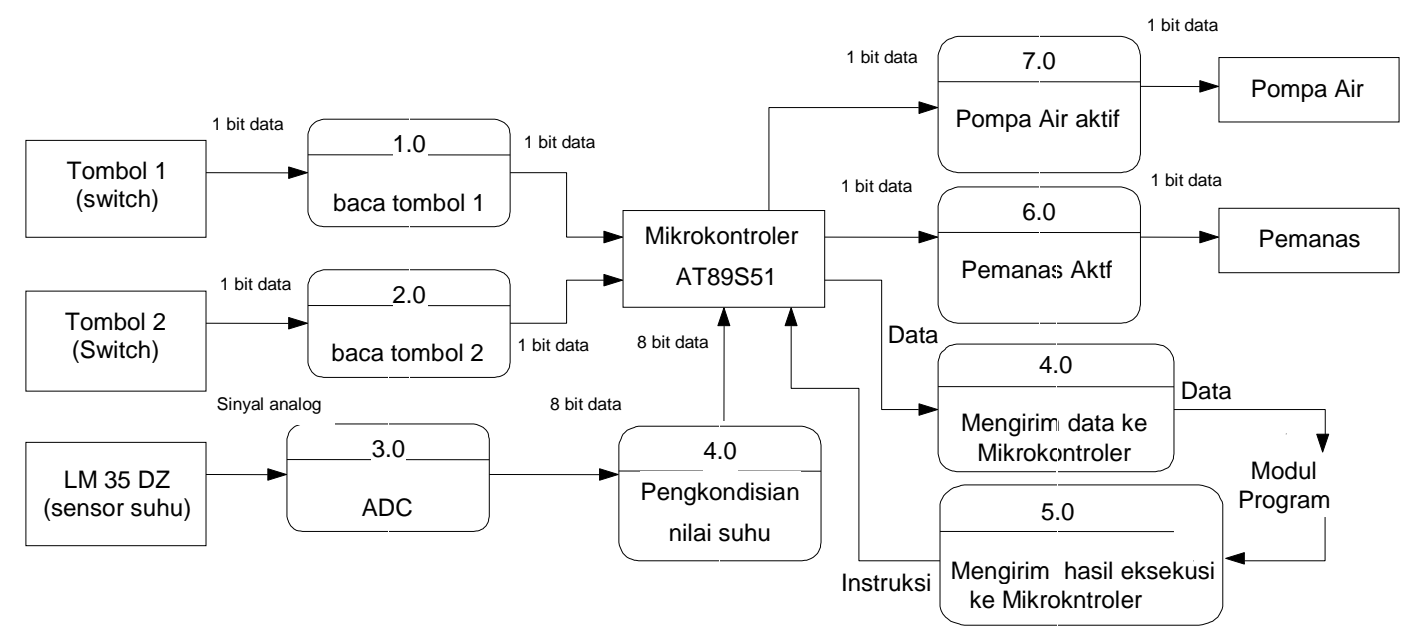

\section{Gambar 3.2 Data Flow Diagram Level 0}

Sistem pengontrolan bak penampungan air ini dapat dijelaskan sebagai berikut. Sistem akan aktif ketika pengguna masuk ke dalam ruang pemandian. Kemudian dilakukan penekanan tombol, tombol 1 untuk kondisi air panas dan tombol 2 kondisi air dingin (normal). Selanjutnya hasil penekanan tombol tersebut akan dilanjutkan proses penerimaan data input yang akan langsung diproses oleh Mikrokontroler AT89S51 'dan setelah itu akan dilanjutkan dengan pembacaan kondisi air pada bak penampungan, jika penekanan tombol 1 maka kondisi pemanas air akan aktif jika tidak maka pompa air sebagai penggerak memompa air akan aktif dan selanjutnya air mengalir. Kondisi suhu panas yang dihasilkan telah ditentukan oleh program berkisar suhu $\pm 36^{\circ} \mathrm{C}$ dan dapat berobah sesuai dengan kebutuhan sipemakainya..

\subsection{Blok Diagram}

Blok Diagram berfungsi sebagai media penggabungan beberapa komponen, yang terdiri dari suatu proses. Blok diagram yang dimaksud dapat dilihat pada gambar 3.3 dibawah ini :

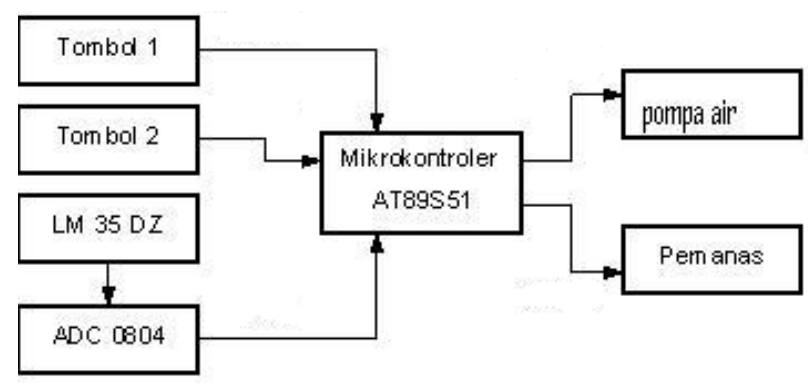

Gambar 3.3 Blok Diagram Alat 
Fungsi dari masing-masing Blok Diagram adalah sebagai berikut :

a. Tombol

Berfungsi sebagai saklar untuk mengaktifkan sistem kondisi air panas dan dingin.

b. Sensor Suhu

Berfungsi sebagai pengukuran suhu pada bak penampungan air, jika kondisi suhu yang diinginkan adalah air panas, sehingga air panas dapat dikontrol sesuai batas kulit manusia.

c. ADC 0804

Berfungsi untuk menerjemahkan keluaran dari sensor suhu LM 35 DZ dari sinyal analog menjadi sinyal digital yang dapat dimengerti oleh mikrokontroler.

d. Mikrokontroler

Berfungsi sebagai pengontrol pemanas air, pompa air 1(AC) dan pompa air 2(AC).

e. Pompa Air

Berfungsi sebagai media penggerak untuk membuka kran pada bak penampungan air.

f. Pemanas Air

Merupakan media untuk memanaskan air pada bak penampungan air.

\subsection{Rancangan Fisik Alat}

Berikut ini disajikan rancangan fisik dari sistem yang dikembangkan :

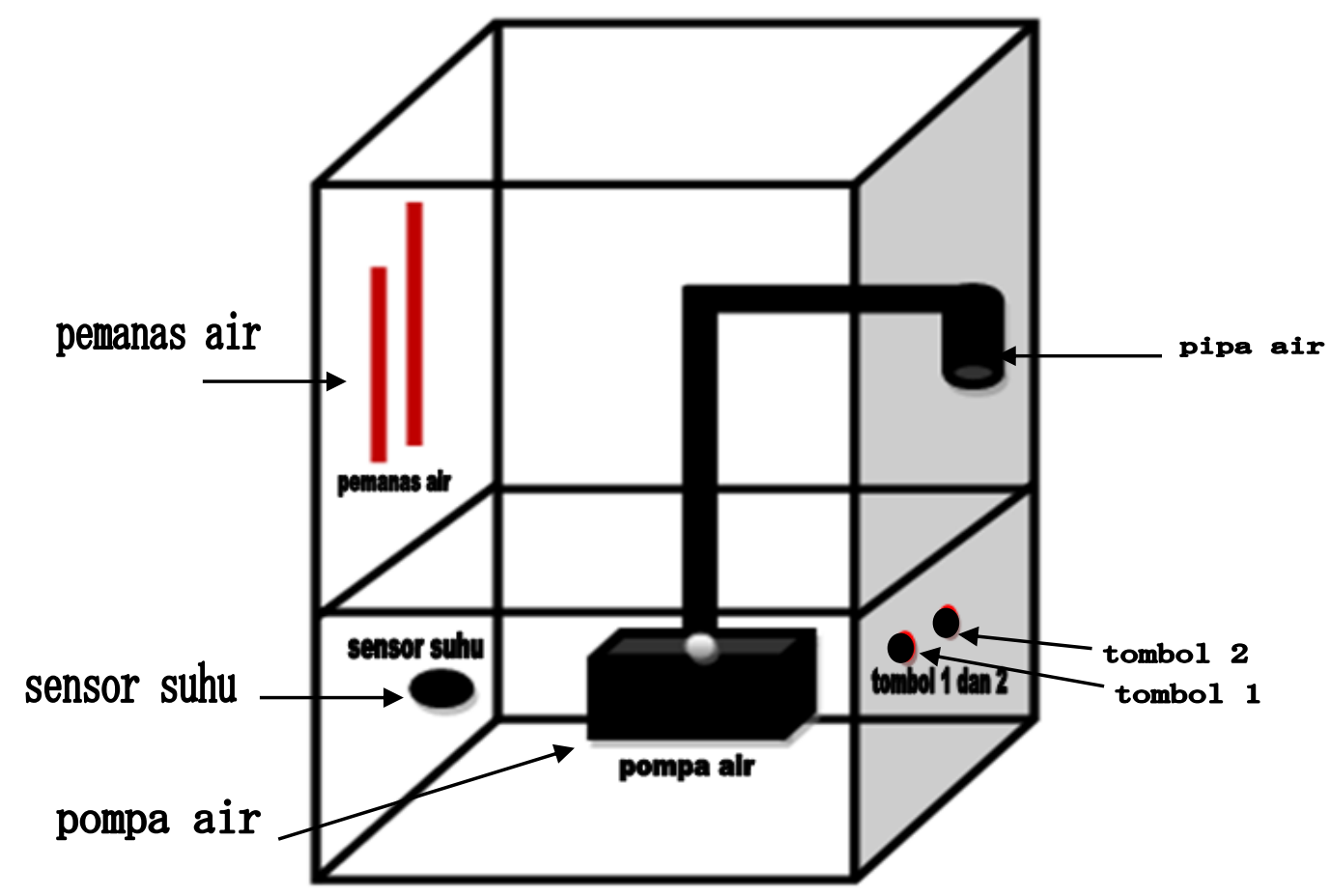

Gambar 3.4 Rancangan Fisik Alat

Rancangan fisik akat tersebut dapat diterangkan sebagai berikut:

1. Melakukan penekanan tombol 1 atau 2, jika kondisi tombol 1 ditekan maka akan menghasilkan pada bak penampungan akan menjadi panas dan kondisi tombol 2 ditekan makan kondisi suhu air normal. 
2. Setelah dsilakukan penekanan, jika tombol 1 ditekan maka selanjutnya proses pembacaan sensor suhu jika suhu air belum mencapai $36^{\circ} \mathrm{C}$ maka pemanas air akan diaktifkan, jika suhu maka pemanas akan dimatikan.

3. Setelah proses pemanasan mencapai suhu yang telah ditentukan maka selanjutnya proses pengaktifan pada pompa air yang berfungsi untuk membuka kran pada bak penampungan.

\subsection{Perancangan Pembuatan dan Pengujian Rangkaian Mikrokontroler AT89S51}

Perancangan rangkaian mikrokontroler AT89S51 diawali dengan pengujian pada bread board. Adapun gambar rangkaian dapat dilihat dibawah ini. Setelah dipastikan hasil pengukuran sesuai atau mendekati teori yang ada maka dapat dipindahkan ke papan PCB. Tahap pemindahan rangkaian ke papan PCB adalah :

1. Rancangan awal jalur PCB dibuat pada kertas milimeter

2. Jalur rangkaian dipindahkan kepapan PCB dengan rugos PCB dan spidol permanen.

3. Papan PCB yang telah bergambar jalur-jalur rangkaian dilarutkan pada perlarut Feri Clhorida ( $\mathrm{FeCl} 3)$.

4. Terminal-terminal tempat pemasangan komponen di bor.

5. Komponen-komponen dirakit pada papan PCB.

6. Rangkaian siap untuk di uji.

Langkah selanjutnya rangkaian diukur dengan pengukur parameter- parameter tegangan logika "0" dan "1". Hasil pengukuran dapat dilihat pada tabel berikut ini :

Tabel 3.1 Pengukuran Parameter Mikrokontroler AT89S51

\begin{tabular}{|c|c|}
\hline Logika Port & Tegangan pada Port 1 MC AT89S51 \\
\hline Low (0) & $0,2 \mathrm{v}$ \\
High (1) & $4,8 \mathrm{v}$ \\
\hline
\end{tabular}

Mikrokontroler bekerja pada dua kondisi logika yaitu kondisi low (0) dimana tegangan yang terbaca pada instrumen pengukuran tegangan didapatkan tegangan port sebesar $0,2 \mathrm{~V}$ yang berarti sistem masih dalam batas ideal. Logika yang kedua yaitu kondisi high (1) dimana tegangan yang terbaca pada instrumen pengukuran tegangan didapatkan tegangan port sebesar 4,8V yang berarti sistem masih dalam batas ideal. Dari kondisi pengukuran diatas, maka rangkaian mikrokontroler AT89S51 telah dapat bekerja dengan baik.

\subsection{Rangkaian Sistem Minimum AT89S51}

Sistem minimum merupakan rangkaian minimum yang digunakan untuk mengaktifkan mikrokontroler. Sistem minimum terdiri dari rangkaian pewaktuan dan rangkaian pencatu daya. Blok rangkaian dari sistem minimum AT89S51 dapat dilihat pada gambar 3.5. 


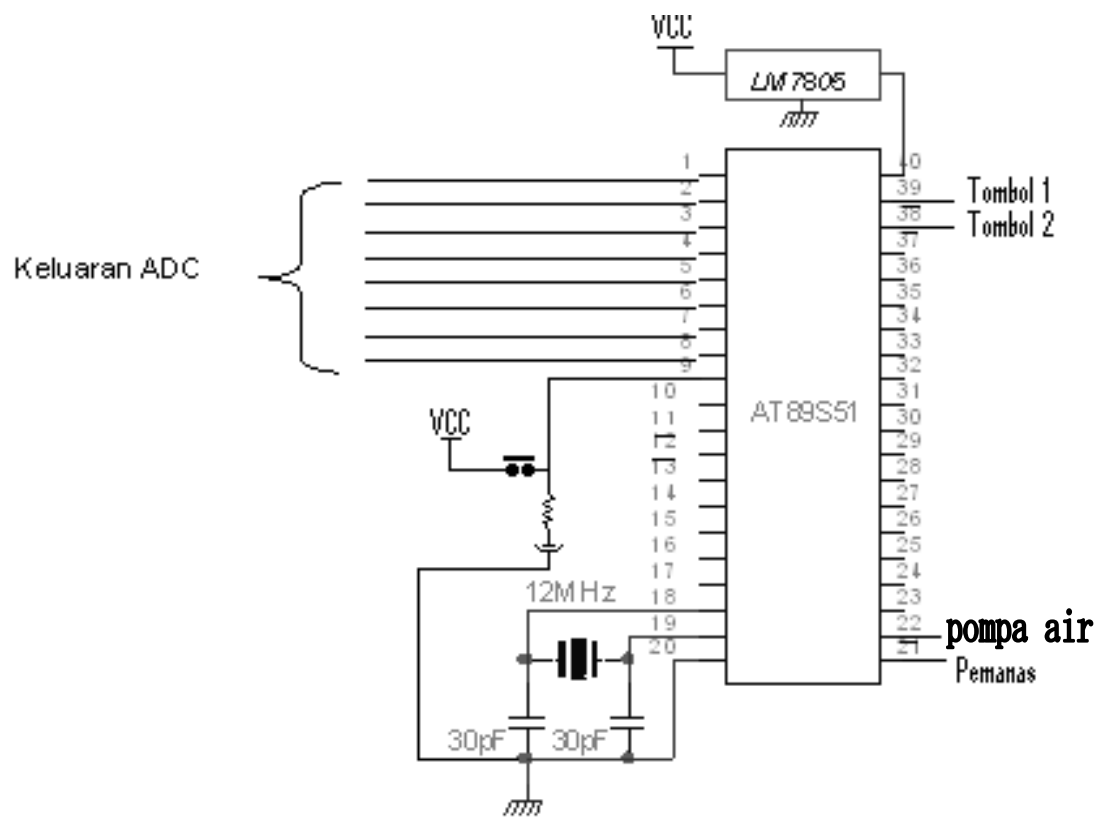

Gambar 3.5 Rangkaian Sistem Minimum Mikrokontroler AT89S51

Pencatu daya sistem minimum berasal dari keluaran IC LM 7805 yang berfungsi sebagai voltage regulator. Keluaran ini juga digunakan untuk memberikan logika high dalam mereset sistem. Sistem akan tereset apabila saklar terhubung, sehingga tegangan 5 volt mengalir ke pin 9 mikrokontroler AT89S51 yang merupakan pin reset. Sinyal pewaktuan digunakan dengan menghubungkan kristal 12 Mhz yang dirangkai ke pin mikrokontroler.

\subsection{Rangkaian Sensor Suhu LM 35 DZ}

Rangkaian driver sensor suhu menggunakan sensor suhu LM 35 DZ. Sensor tersebut digunakan untuk mengecek suhu pada bak penampungan. Blok rangkaian dari rangkaiannya dapat dilihat sebagai berikut:

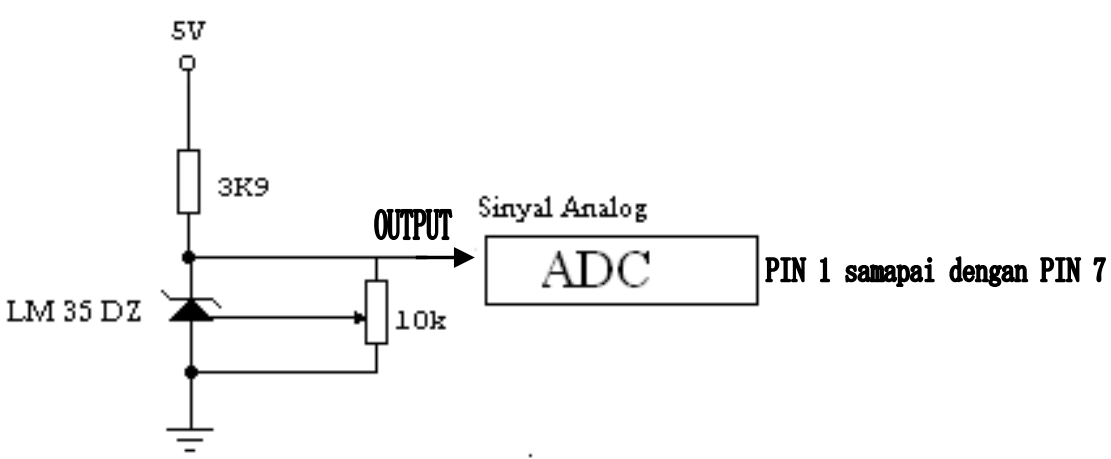

Gambar 3.6. Driver Sensor Suhu LM 35 DZ 
Sensor suhu LM $35 \mathrm{DZ}$ dapat mendeteksi temperatur dengan range $0^{\circ}-100^{\circ} \mathrm{C}$ dan gain sensor mencapai $10 \mathrm{mV} /{ }^{\circ} \mathrm{C}$. Pengontrolan suhu pada bak penampungan menggunakan kisaran suhu antara $38^{\circ} \mathrm{C}$ hingga $42^{\circ} \mathrm{C}$. Dengan demikian range besaran tegangan yang akan dikirimkan sensor suhu LM 35 DZ ke ADC 0804 tampak pada tabel 3.2.

Tabel 3.2. Pengunaan Range Suhu Pada Sistem

\begin{tabular}{|c|c|}
\hline Suhu Sistem $\left({ }^{\mathbf{0}} \mathbf{C}\right)$ & Tegangan $(\mathbf{m V})$ \\
\hline $38<\mathrm{T}<42$ & $380,1<\mathrm{V}<420$ \\
\hline
\end{tabular}

Orde milivolt merupakan nilai yang sangat sulit diukur menggunakan alat ukur manual. Oleh karena itu, akan sulit membandingkan pengukuran suhu manual dengan tabel nilai keluaran komponen LM $35 \mathrm{DZ}$ dari pabrik. Implementasi dari pengukuran suhu $38^{\circ} \mathrm{C}$ hingga $42^{0} \mathrm{C}$, dilakukan dengan mengukur nilai keluaran dari ADC 0804. Pada range suhu tersebut, dapat diukur nilai biner yang keluar dari ADC 0804. Nilai biner tersebut yang akan digunakan dalam pengendalian menggunakan mikrokontroler AT89S51.

\subsection{Rangkaian ADC 0804}

ADC 0804 merupakan perangkat yang mengkonversikan nilai sinyal analog ke digital. Pada ADC 0804, terdapat delapan input analog dan delapan data output. Kemudian terdapat juga pin-pin control yang bertujuan untuk mengaktifkan ADC 0804. Rangkaian ADC dapat dilihat pada gambar 3.7.

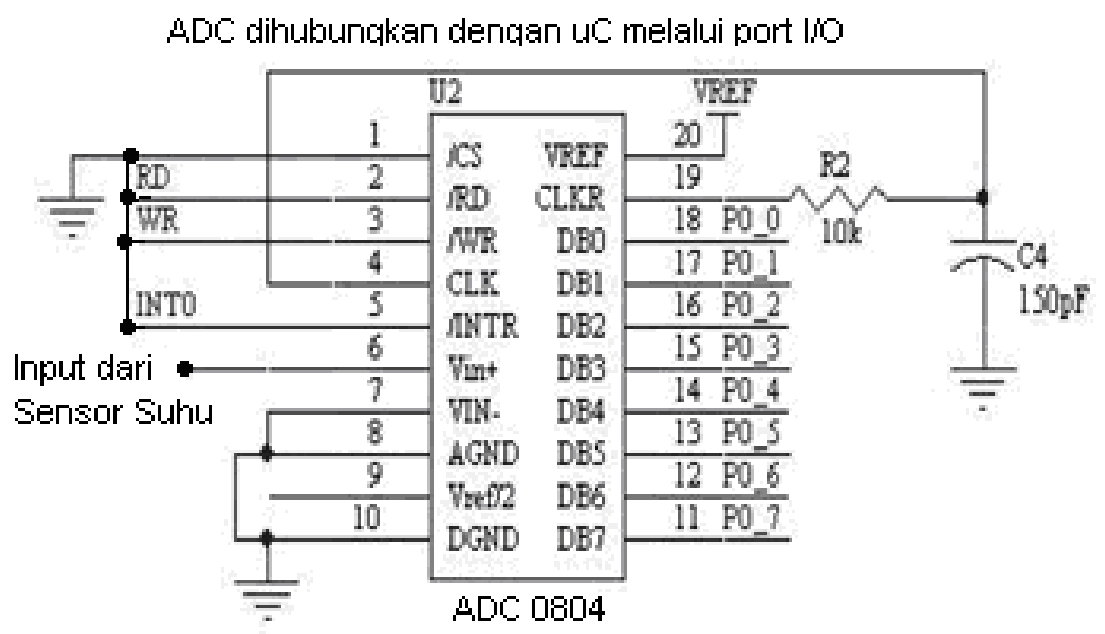

Gambar 3.7. Rangkaian ADC 0804

a. Prinsip kerja rangkaian ADC 0804:

R2 dan C4 berfungsi sebagai rangkaian clock pada ADC 0804. Input tegangan analog diberikan oleh VR1. Interkoneksi dengan mikrokontroler AT89S51 dilakukan melalui pin RD, WR dan INT0 yang dihubungkan ke ground. INT0 sebagai indikator konversi data selesai. INT0 dapat dihubungkan ke interrupt pada mikrokontroler. Data hasil konversi dapat dibaca pada port 1 pada mikrokontroler. 
b. Kalibrasi step ADC

Keluaran dari sensor suhu LM 35 DZ akan diterjemahkan menjadi bilangan biner oleh ADC. Step ADC berjumlah 255, perlu dikalibrasi peningkatan setiap step pada ADC dengan keluaran sensor suhu LM 35 DZ. Ini dilakukan dengan mengatur tegangan referensi pada ADC yaitu pada pin Vref (+) dan Vref (-). Dengan memasukkan tegangan referensi sebesar 5 Volt DC, kenaikan setiap step ADC menjadi $5 / 255=0,019 \mathrm{~V}=19 \mathrm{mV}$ (yang berarti pembacaan ADC akan berubah sebesar 1 step jika terjadi perubahan sebesar $19 \mathrm{mV}$. Step pada sensor LM 35 DZ sebesar $10 \mathrm{mV}\left(1^{0} \mathrm{C} / 10 \mathrm{mV}\right)$ maka dapat kita anggap bahwa ADC akan berubah satu step jika terjadi perubahan suhu sebesar $2{ }^{\circ} \mathrm{C}$. Berdasarkan analisa di atas maka didapatkan tabel 3.3 ebagai berikut.

Tabel 3.3. Keluaran Port ADC

\begin{tabular}{|c|c|}
\hline Suhu Sistem $\left({ }^{\mathbf{0}} \mathbf{C}\right)$ & Biner \\
\hline 30 & $11011110 \mathrm{~b}$ \\
\hline 32 & $11100001 \mathrm{~b}$ \\
\hline 34 & $11100010 \mathrm{~b}$ \\
\hline 36 & $11100011 \mathrm{~b}$ \\
\hline
\end{tabular}

\subsection{Rangkaian Driver Pemanas}

Bentuk dasar pemanas yang paling sederhana terdiri dari sebuah element yang dapat mengeluarkan suhu panas, sehingga akan menghasilkan suhu ruangan yang stabil Untuk lebih jelasnya dapat dilihat pada rancangan blok pada gambar 3.8 di bawah ini :

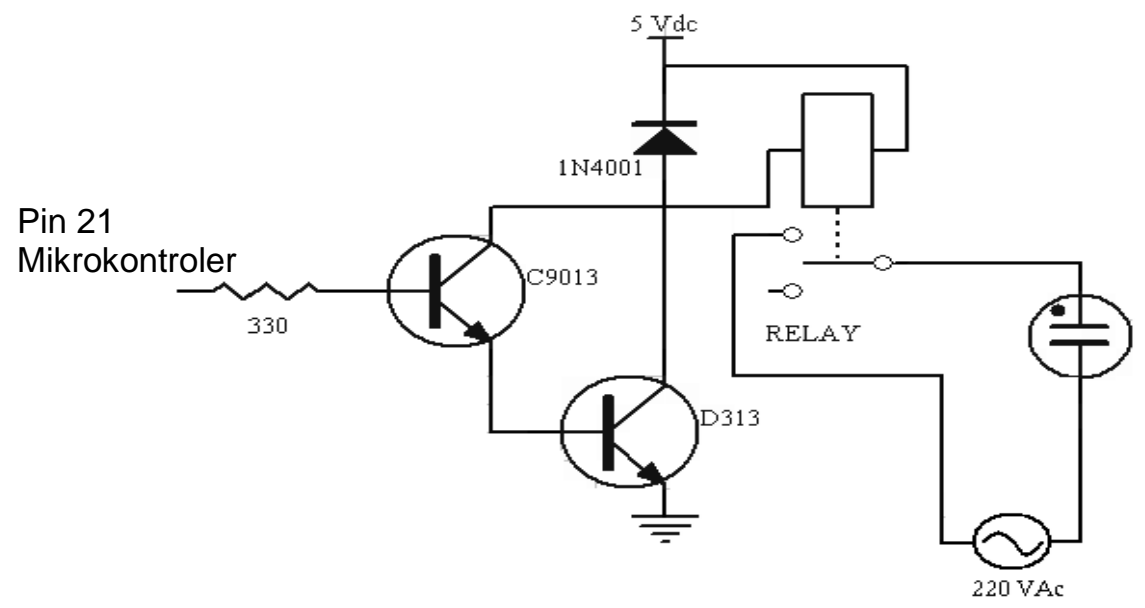

Gambar 3.8. Rangkaian Driver Pemanas

Blok rangkaian driver ini berfungsi sebagai penggerak relay yang dapat mengaktifkan dari sistem pemanas. Driver ini menggunakan transistor Darlington sebagai saklar elektronis untuk menghidupkan relay. Karena relay merupakan sebuah peralatan induksi, digunakan sebuah dioda pelindung untuk melindungi rangkaian dari induksi diri relay. 
Driver ini pada saat dihidupkan diperlukan kiriman sinyal logika tinggi (high) yang akan mengaliri basis transistor. Pada alat yang dibuat berupa pin 12 pada mikrokontroler. Besar tegangan basis yang melewati tegangan breakdown, maka arus akan mengalir dari kolektor ke emitor untuk menghidupkan relay.

\subsection{Rangkaian Pompa Air}

Bentuk dasar driver pompa air tediri dari sebuah relay yang digunakan untuk menghidupkan pompa air. Untuk lebih jelasnya dapat dilihat pada rancangan blok pada gambar 3.9. di bawah ini :

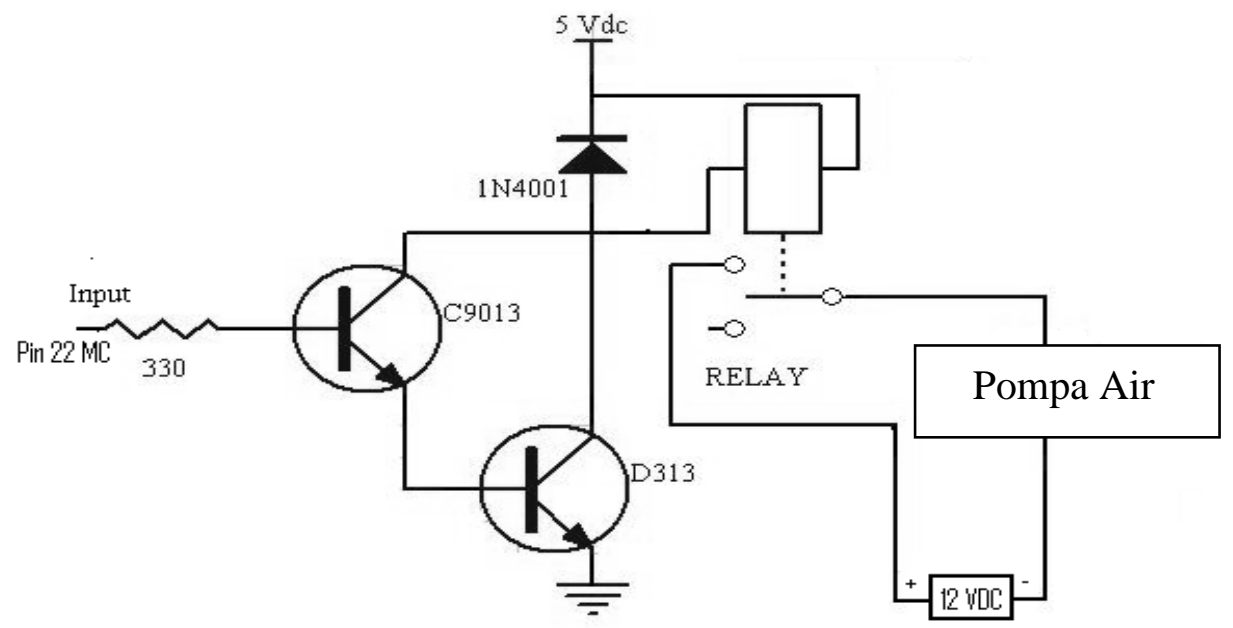

\section{Gambar 3.9. Rangkaian Driver Pompa Air}

Blok rangkaian driver ini berfungsi sebagai penggerak relay yang dapat menghidupkan pompa air. Driver pada rangkaian Pompa Air berfungsi sebagai saklar. Seperti diketahui relay aktif berdasarkan bit-bit yang diterimanya, untuk itu diperlukan transistor sebagai penyambung dan pemutus arus.

\subsection{Rancangan dan Logika Program}

Berikut ini akan digambarkan logika program dari peralatan yang dirancang. Sebagai langkah awal perancangan program diwujudkan dalam bentuk flowchart. Adapun flowchart yang dimaksud adalah : 


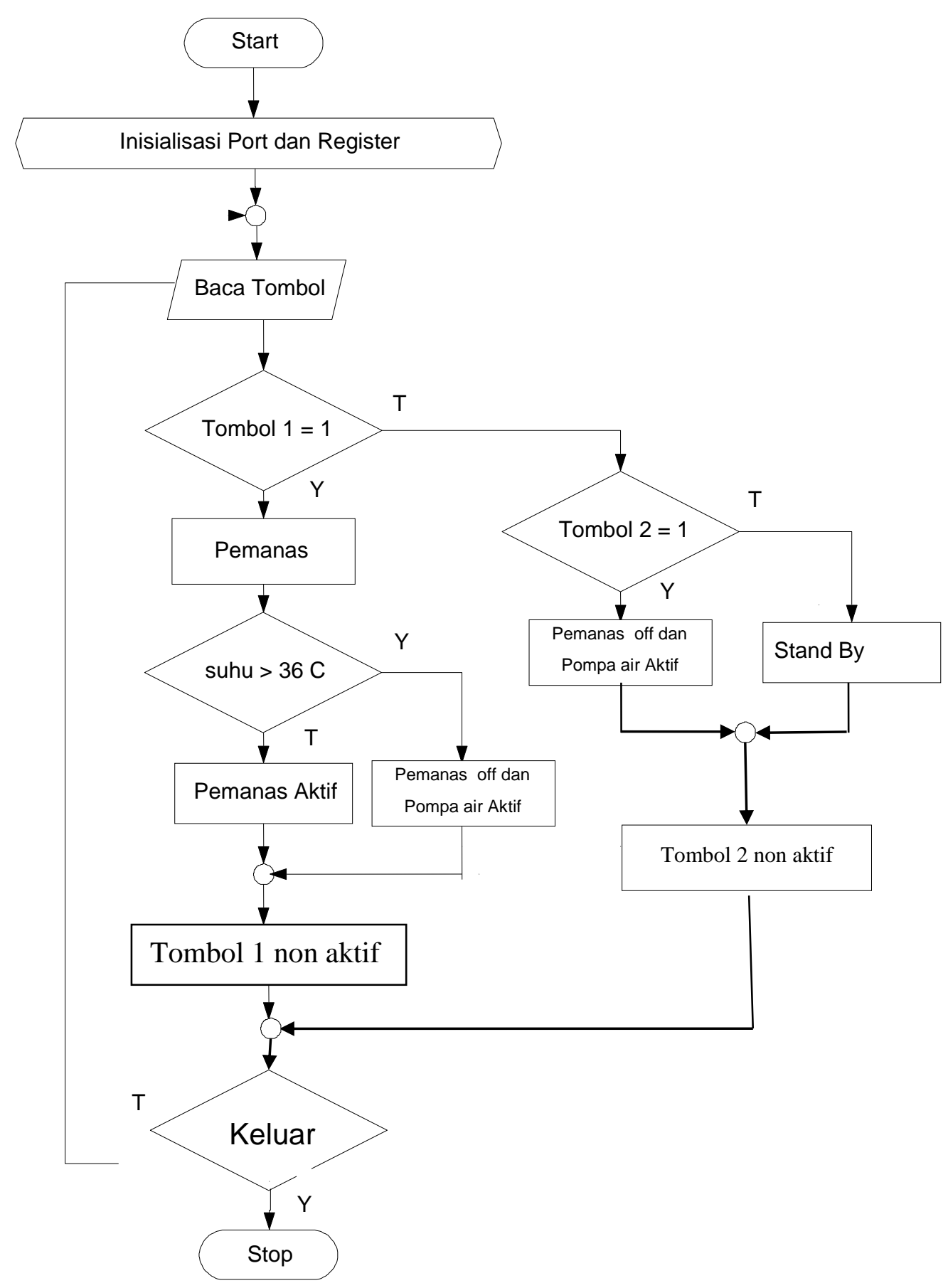

Gambar 3.10 Flowchart Program

\subsection{Modul Program}

Modul ini berisi deklarasi dari port-port dan register yang digunakan. Pada modul ini juga diberikan nilai awal pada masing-masing port dan register tersebut. Listing program dari modul inisialisasi port dapat dilihat sebagai berikut: 


$\begin{array}{ll}\text { MOV p0,\#00h } & \\ \text { MOV p1,\#00h } & \\ \text { MOV p2,\#00h } & \\ \text { MOV p3,\#00h } & \\ \text { MOV R0,\#00h } & \\ \text { MOV R2,\#00h } & \\ \text { MOV R4,\#00h } & \\ \text { MOV R5,\#00h } & \\ \text { MOV R6,\#00h } & \\ \text { MOV R7,\#00h } & \\ \text { SUHU } & \text { EQU p1 } \\ \text { Tombol_1 } & \text { EQU p0.0 } \\ \text { Tombol_2 } & \text { EQU p0.1 } \\ \text { Keylogger } & \text { EQU p2.1 } \\ \text { pemanas } & \text { EQU p2.0 }\end{array}$

Modul yang digunakan berfungsi untuk mengatur suhu air berkisar antara $38^{\circ}-42^{\circ} \mathrm{C}$. Untuk keperluan itu digunakan pemilihan kondisi dari nilai yang dikeluarkan ADC 0804 yaitu DEH dan E2H. Jika suhu kurang dari $38^{\circ} \mathrm{C}$, pemanas dimatikan dan ketika suhu lebih dari $42^{\circ} \mathrm{C}$, pemanas dimatikan. Berikut adalah listing program dari modul baca sensor suhu.

IF R0 > \# 2h THEN ACALL pemanas_off

IF R0 < \#deh THEN ACALL pemanas_on

\subsection{Langkah-Langkah Pemrograman}

Adapun langkah yang harus dilalui dalam pemrograman mikrokontroler AT89S51 sebagai berikut:

1. Pengetikan program, dalam hal ini dapat menggunakan salah satu program editor teks seperti edit, notepad, skn dan lain-lain. Program yang diketikkan disimpan dalam file dengan ekstensi .asm.

2. Program tersebut kemudian dikompilasi dengan menggunakan program MA51.EXE versi 1.14 keluaran Micro Computer Control Corp tahun 1993, dengan syntaks : MA51 nama_program.asm. Hasil kompilasi ini akan menghasilkan file dengan ekstensi lst dan obj. File .lst berisi keterangan tentang proses kompilasi dan kesalahan dalam pemrograman. Sedangkan file obj tercipta jika tidak terjadi kesalahan pada proses kompilasi program.

3. Selanjutnya file .obj yang tercipta dilink untuk menghasilkan file .hex dan file .map. Syntaksnya adalah : ML51 nama_program.obj format (ihex)

4. Setelah proses linking berhasil dilakukan, selanjutnya file dengan ekstensi .hex harus diubah menjadi bentuk file biner dengan ekstensi .bin. Untuk merubah file tersebut dapat digunakan program HEXBIN.EXE dengan syntaks : HEXBIN nama_program.hex

5. Langkah selanjutnya adalah proses pengisian file dengan ekstensi .bin tersebut ke dalam mikrokontroler AT89S51. Dalam hal ini digunakan Serial PEROM Programmer ke komputer PC dan diaktifkan, kemudian tancapkan IC mikrokontroler AT89S51 yang hendak diprogram pada soket yang tersedia. Untuk masuk ke program ketikkan : SFPP5115.EXE 
6. Mikrokontroler AT89S51 yang diisi harus kosong terlebih dahulu. Untuk mengosongkan Flash PEROM tekan huruf " $D$ ". Untuk mengecek apakah Flash PEROM tersebut sudah kosong tekan huruf " $B$ ", sedangkan untuk melakukan pengisian tekan huruf " $F$ " dan masukkan nama file .bin yang telah diprogram sebelumnya.

7. Setelah IC mikrokontroler AT89S51 diprogram, IC tersebut siap digunakan pada sistem yang dirancang.

\subsection{Pengoperasian Sistem}

Langkah-langkah pengoperasian alat adalah sebagai berikut :

a. Rangkaian mikrokontroler AT89S51, rangkaian driver, dan rangkaian catu daya dihubungkan dan dipasang.

b. Setelah memastikan seluruh rangkaian sudah terpasang dengan benar atau tidak ada yang terhubung singkat, maka peralatan di aktifkan.

\section{IMPLEMENTASI}

\subsection{Implementasi Sistem}

Tahap implementasi sistem merupakan salah satu tahap dalam daur hidup pengembangan sistem, dimana tahap ini merupakan tahap meletakkan sistem bak penampungan air kamar mandi siap untuk dipakai, beberapa aktifitas secara berurutan berlangsung dalam tahap ini, yakni mulai dari menerapkan rencana implementasi, melakukan kegiatan implementasi, dan tindak lanjut implementasi. Rencana implementasi perlu dibuat terlebih dahulu, supaya implementasi berjalan dengan baik dan sesuai dengan yang diharapkan. Rencana implementasi ini dimaksudkan untuk mengatur biaya serta waktu yang dibutuhkan selama tahap implementasi. Implementasi dari sistem Robot Pemadam Api ini dapat dilakukan dengan langkah-langkah sebagai berikut:

1. Pasang power supply $5 \mathrm{~V}$ untuk menghidupkan sistem pada bak penampungan air pada kamar mandi.

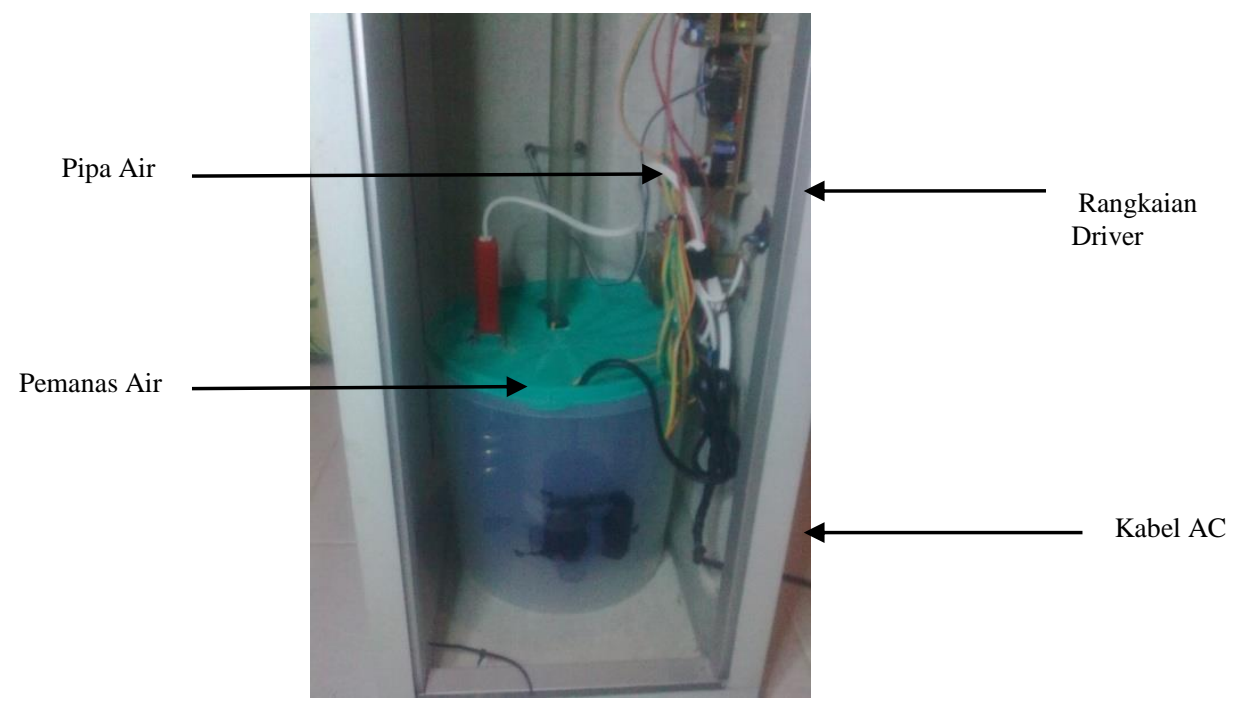

Gambar 4.1: Bak penampungan dalam kondisi aktif 
2. Masukkan air kedalam bak penampungan, langkah selanjutnya adalah penekanan tombol 1 atau tombol 2, jika kondisi air yang di inginkan dalam kondisi normal maka lakukan penekanan tombol 2, selanjutnya air akan mengalir dengan aktifnya pompa air, jika ingin mematikan pompa air maka tekan kembali tombol 2.

3.

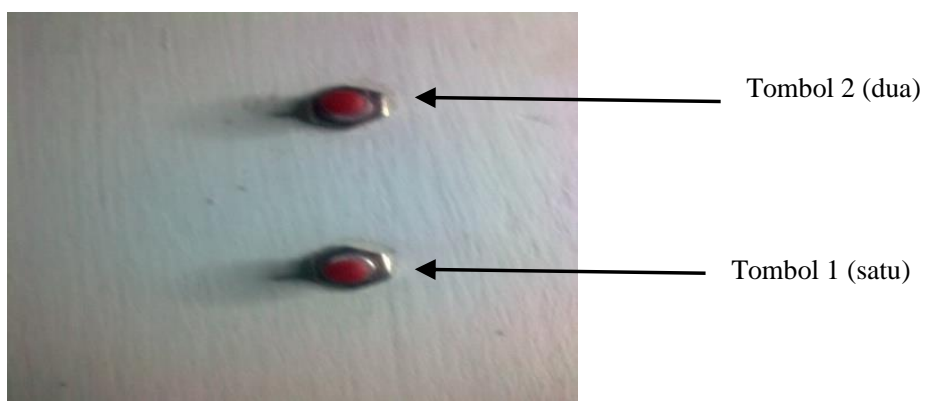

Gambar 4.2 : switch sebagai tombol aktif

4. Tombol 1 apabila di tekan maka sistem pemanasan air akan aktif pada suhu $36^{\circ} \mathrm{C}$, selang beberapa lama terjadi pemanasan air, setelah itu pemanas akan otomatis akan mati dengan sendirinya dan pompa air akan aktif untuk mengeluarkan air pada shower kamar mandi, jika ingin mematikan pompa air maka tekan kembali tombol 1. Tombol yang dihubungkan dengan pemanas air adalah tombol 1.

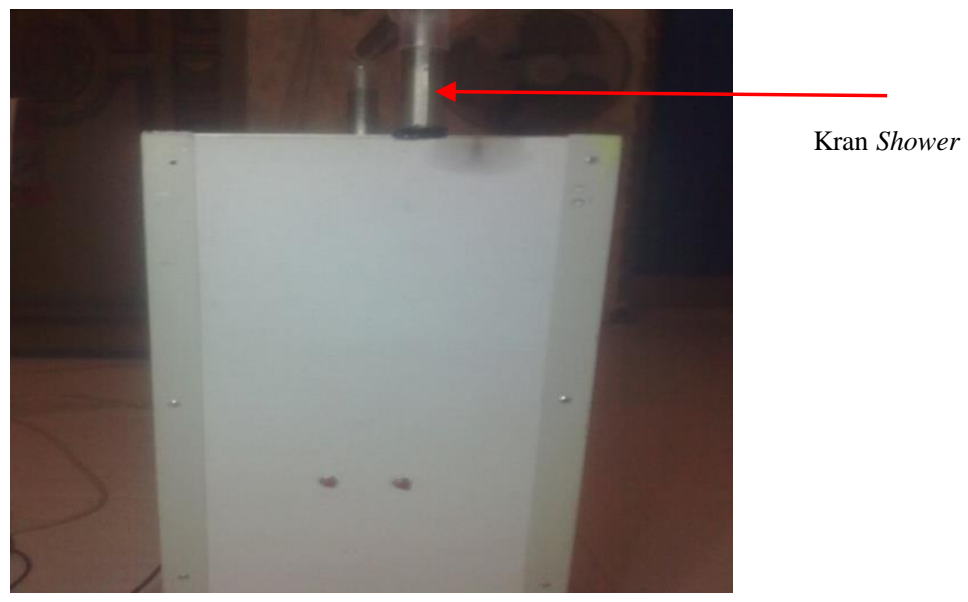

Gambar 4.3 : Pompa air aktif

\section{KESIMPULAN}

Berdasarkan analisa dan hasil penelitian dalam perancangan dan pembuatan alat ini, yang berpedoman pada buku-buku yang berhubungan dengan alat tersebut, serta permasalahan yang timbul selama mendesain maka dapat diambil beberapa kesimpulan sebagai berikut : 
1. Sistem Pengontrol Shower dan Pengisian Bak Penampungan ini menggunakan beberapa entity didalam menunjang sistem, diantaranya sensor suhu, tombol, pompa air AC, LM 35 DZ, ADC 0804, mikrokontroler, dan pemanas.

2. Sistem akan aktif ketika pengguna memasuki ruang pemandian dan tubuh pengguna dideteksi oleh sensor suhu.

3. Shower akan berhenti mengalir ketika pengguna telah keluar dari ruang pemandian atau air pada bak penampungan telah kosong.

4. Kosongnya bak penampungan akan mengaktifkan sistem untuk memompa air dari sumber air ke bak penampungan.

5. Sistem pengontrol shower dan pengisian bak penampungan ini menggunakan mikrokontroler AT89S51 sebagai media pemrosesan setiap masukan yang diterima dan menghasilkan keluaran sesuai dengan rancangan modul program.

\section{DAFTAR PUSTAKA}

Depari, Ganti. 2003. Belajar Teori dan Ketrampilan Elektronika. Bandung : PT. Elex Media Computindo.

Edi Laksono (Penterjemah). Teknik Kontrol Automatik Jilid 1 Edisi 2. Jakarta : Erlangga.

Jaenal, Arifin: Sistem Akuisisi Data Suhu Menggunakan Mikrokontroller AT89S51: www.toko-elektronika.com/tutorial/ADC.html

Jogiyanto, HM. 2000. Intisari Elektronika. Jakarta : PT. Elex Media Computindo

Malik, dkk. 2004. Bereksperimen dengan Mikrokontroler 8051. Jakarta : PT. Gramedia.

Ratna, Wulandari, P. 2006. Rancang Bangun Sistem Kontrol dan Monitoring Suhu Ruangan Via telepon. Surabaya: Institut Teknologi Sepuluh Nopember.

Sharon, D et, Al. 2004. Robot dan Otomatisasi Industri. Jakarta : PT Elex Media Computindo

Sukiswo. 2005. Perancangan Telemetri Suhu dengan Modulasi Digital FSK-FM. Semarang: Universitas Diponegoro.

Tim Lab. Mikrokontroler, 2007. Pemrograman Mikrokontroler AT89S51 Dengan C/C++ dan Assembler. Yogyakarta: Andi Offset. 